\title{
Maternal solitude before the new guidelines in SARS-COV-2 times: a Brazilian cutting
}

GE Revista Gaúcha 10. de Enfermagem

How to cite this article: Paixão GPN, Campos LM, Carneiro $J B$, Fraga CDS. Maternal solitude before the new guidelines in SARS-COV-2 times: a Brazilian cutting. Rev Gaúcha Enferm. 2021;42(spe):e20200165 doi: https://doi.org/10.1590/19831447.2021.20200165 aniversidade do Estado da Bahia (UNEB), Colegiado de Enfermagem. Senhor do Bonfim, Bahia, Brasil.

- Universidade Federal da Bahia (UFBA), Programa de Pós-Graduação em Enfermagem e Saúde. Salvador Bahia, Brasil.

\author{
A solidão materna diante das novas orientações em \\ tempos de SARS-COV-2: um recorte brasileiro \\ Soledad materna ante las nuevas directrices en \\ tiempos del SARS-COV-2: un corte brasileño
}

\section{Gilvânia Patrícia do Nascimento Paixão \\ Luana Moura Campos ${ }^{\mathrm{b}}$ \\ Jordana Brock Carneiro ${ }^{b}$ \\ Chalana Duarte de Sena Fraga ${ }^{a}$}

\section{ABSTRACT}

Aim: To reflect on the lonely experience of women during the pregnancy-puerperal cycle in times of pandemic by the SARS-CoV-2 virus.

Method: Theoretical-reflective study on the new Brazilian guidelines for care for women during pregnancy, childbirth and postpartum in times of Covid-19 and its influence on the exacerbation of maternal Ioneliness. The discussion about the transformations of women in this period refers to Maldonado's studies.

Results: Motherhood is a lonely process for women. The new technical norms that are in force bring important changes in the assistance to this cycle, mainly with regard to the importance of social distance, which intensifies the feeling of loneliness and helplessness.

Final considerations: This reflection can guide health professionals, especially the work of nurses in the scope of obstetrics, so that during the assistance to women in the pregnancy-puerperal cycle, they pay attention to the subtlety of feelings of loneliness that can interfere with maternal well-being fetal.

Keywords: Coronavirus infections. Anxiety. Peripartum period.

\section{RESUMO}

Objetivo: Refletir acerca da vivência solitária da mulher durante o ciclo gravídico-puerperal em tempos de pandemia pelo vírus SARS-COV-2.

Método: Estudo teórico-reflexivo sobre as novas diretrizes brasileiras para atendimento às mulheres na gestação, parto e pós-parto em tempos de COVID-19 e sua influência na exacerbação da solidão materna. A discussão acerca das transformaç̧ões da mulher nesse período remete aos estudos de Maldonado.

Resultados: A maternidade é um processo solitário para as mulheres. As novas normas técnicas que estão vigorando trazem importantes mudanças na assistência a esse ciclo, principalmente no que tange a importância do distanciamento social, que intensifica o sentimento de solidão e desamparo.

Considerações finais: Esta reflexão pode nortear os profissionais de saúde, sobretudo enfermeiras do âmbito da obstetrícia, para que durante a assistência à mulher no ciclo gravídico-puerperal atentem-se para as sutilezas de sentimentos de solidão que podem interferir no bem-estar materno-fetal.

Palavras-chave: Infecções por coronavírus. Ansiedade. Período periparto.

\section{RESUMEN}

Objetivo: Reflexionar sobre la experiencia solitaria de las mujeres durante el ciclo embarazo-puerperal en tiempos de pandemia por el virus SARS-COV-2.

Método: Estudio teórico-reflexivo sobre las nuevas pautas brasileñas para el cuidado de las mujeres durante el embarazo, el parto y el posparto en tiempos de Covid-19 y su influencia en la exacerbación de la soledad materna. La discusión sobre las transformaciones de las mujeres en este período se refiere a los estudios de Maldonado.

Resultados: La maternidad es un proceso solitario para las mujeres. Las nuevas normas técnicas vigentes traen cambios importantes en la asistencia a este ciclo, principalmente con respecto a la importancia de la distancia social, que intensifica el sentimiento de soledad e impotencia.

Consideraciones finales: Esta reflexión puede orientar a los profesionales de la salud, especialmente la labor del enfermero en el ámbito de la obstetricia, para que durante la asistencia a la mujer en el ciclo embarazo-puerperal, preste atención a la sutileza de los sentimientos de soledad que pueden interferir con el bienestar materno fetal.

Palabras clave: Infecciones por Coronavirus. Ansiedad. Periodo periparto. 


\section{口INTRODUCTION}

The context of the pandemic caused by the new coronavirus (SARS-CoV-2) in conjunction with the alarming growth in the number of Covid-19 cases requires social distance. The strictness of this measure for pregnant women and women who have recently given birth due to an increased preoccupation with the maternal-fetal well-being ${ }^{(1)}$ can impact the full experience of motherhood and result in a lonelier experience during pregnancy, childbirth and the puerperium.

It is possible to affirm that the pregnancy-puerperal cycle is often experienced by women in a solitary way, a fact resulting from the social construction about motherhood, which determines that the responsibility in the role of child care belongs to the mother. This reality encompasses a multiplicity of new tasks generated by motherhood, ranging from going to prenatal consultations to meeting the constant needs that arise with the arrival of the newborn $(\mathrm{NB})^{(2)}$. Thus, even though they are in the company of people, women can experience a feeling of loneliness, which is aggravated in contexts of social distance, such as the one currently experienced.

Added to this are the biological and psychological changes expected at this stage, resulting mainly from significant hormonal changes, making these women more susceptible to mental illness. In this regard, Maldonado characterizes that the period involved from pregnancy to the puerperium is a moment of crisis, which is marked by the need for transformation and restructuring of this character, in various dimensions ${ }^{(3)}$. Recognizing this phase of intense transformations in the construction of maternity, the role of nursing is highlighted especially in prenatal care, since it is essential to be attentive to the specificities experienced by each woman, in order to prepare them to deal with eventual moments of $\mathrm{crisis}^{(4)}$.

Within this context of vulnerability, it is possible to affirm that risk events experienced by the mother and her child contribute to worsening this crisis, with the experience of an ambivalent feelings being common: if on the one hand there is the happiness of gestating and giving birth to her (your) child, on the other hand, these moments are linked to feelings of fear, insecurity and uncertainty ${ }^{(3-5)}$. To exemplify, a Chinese study revealed that, socially removed and overwhelmed with information about the progression of the numbers of confirmed cases of Covid-19 and its mortality rate, pregnant Chinese women showed a significant increase in depressive symptoms, when compared to pre-pandemic numbers referring to this audience ${ }^{(6)}$.

It should be noted that, although women of reproductive age have been affected to a lesser extent by the virus, when they are pregnant or have recently given birth, they may experience worsening health ${ }^{(1)}$. This is because researchers, based on investigations of infections caused by viruses analogous to the coronavirus, suggest a potential negative perinatal outcome, such as: need for assisted ventilation for women, preterm delivery, fetal growth restriction, abortion and fetal death. In addition, physiological adaptations during the pregnancy-puerperal cycle can increase susceptibility to respiratory infections ${ }^{(1,7)}$.

As a result of this, pregnant women started to be considered by the Brazilian Ministry of Health (MS) as a risk group for Covid-19 on April 9, 2020, with different measures being adopted for this group across the country, in order to reduce the chances of contagion. Although necessary, these guidelines have hindered the experience of many women in relation to the processes of gestating, giving birth and becoming a mother, mainly due to the need for social distancing, which can be decisive for the greater fragility of these women ${ }^{(6)}$.

In this perspective, it is relevant to reflect on the possible impacts generated by the changes in care during the SARS-CoV-2 pandemic in the maternal experience. This is because it is essential to understand the repercussions that all these changes have generated for women, so that the professionals involved in assisting this group, especially nurses, who have a prominent role in care throughout the postpartum pregnancy period and in facing COVID-19-19, can employ the most individualized, comprehensive and humanistic care possible, despite the context of necessary protective and preventive measures. Thus, this work proposes a reflection on the lonely experience of women during the pregnancy-puerperal cycle in times of the pandemic caused by the SARS-CoV-2 virus.

\section{METHOD}

This is a theoretical-reflective study instigated by the changes identified by obstetric nurses in the lives of women during pregnancy and childbirth in the context of the Covid-19 pandemic. The reflexive approach was based on the theoretical assumptions of Maldonado ${ }^{(3)}$, and the existing national and international literature on the subject. The choice for the theoretical basis in Maldonado is due to the fact that the researcher has been studying the issues surrounding psychology in pregnancy, childbirth and the puerperium and its changes in the life and health of women for over forty years, contributing for health professionals to understand the peculiarities of this phase. In addition, the experiences lived by the authors in the care practice for women in the pregnancy-puerperal cycle during the pandemic are added 
to this textual production, interfacing with the exacerbation of loneliness experienced by women in this period.

As this is not a literature review study, the content created was structured, above all, by material collected by the authors, who focused on technical standards and scientific articles produced during the pandemic period. From the exploration of this material, the authors presented reflections based on interpretations about the consulted literature linked to their own reflections on professional nursing practice. Thus, the reflection was presented on three topics: The solitary gestation, Loneliness in childbirth, and The exacerbation of puerperal loneliness.

\section{The solitary gestation}

Motherhood is built procedurally long before the conception of the fetus, and it can be said that the woman is prepared for this event since childhood, through playful activities, such as playing with dolls, going through adolescence in which the first affective relationships occur and reaching the adult stage in which the ideations between being a mother or not take place. This decision is impacted by generational and cultural aspects related to the social constructions of women and their families ${ }^{(3)}$.

Maldonado characterizes pregnancy as a crisis situation inherent to the woman's vital development cycle, with the need for assistance from the entire family system so that this phase can be well overcome, as the author understands that the pregnancy is not something exclusive to the woman, but that of the family ${ }^{(3)}$. In the middle of this pandemic, and in the face of fear of the possibility of infection by a dangerous virus, pregnancy has been a period of greater fragility, with an aggravating need for social distance.

To consciously ponder the theme, it is important to reflect on the construction of motherhood, which happens as a ritual, covering, among other things, the preparation of the environment to receive the newborn. Upon discovering that she is pregnant, the woman then imbues herself with information and prepares for the arrival of the newborn. Regardless of socioeconomic conditions, pregnant women usually prepare the layette, acquiring and/or sharing clothing and utensils to be used by the child with other people from their social life. However, due to the pandemic context that suspended non-essential activities, including most of the stores and commercial activity, the performance of this rite has been hampered. Linked to this, the construction of motherhood also involves the sharing of knowledge, especially based on reports of the experiences of women who have already undergone this process. This transmission of common knowledge occurs in a very natural way through the sharing of experiences between family members and those with close relationships with the mother, or through groups of pregnant women made possible by health services and usually mediated by nurses, with an important role in bringing the pregnant woman closer to the "being a mother". However, these moments of social sharing are surrounded by the barriers of social distance.

Although under restrictive circumstances as to leaving home, visits to prenatal consultations are still maintained and must be ensured by health services, given the indispensability of this space, making it even more important when considering the removal of women from their social environment. Thus, in addition to assessing maternal-fetal well-being, the professionals involved (nurses and doctors) have the role of dialoging with women on broad issues, covering the themes related to pregnancy, childbirth, the puerperium and care of the NB, as well as answering questions and issues that may bring on restlessness. However, during the pandemic, the continued supply of these spaces requires a restructuring of service.

The reorganization of prenatal care, guided by the Manual of Recommendations for Assistance to Pregnant Women and Woman in Postpartum in the face of the Covid-19 Pandemic, provides that the pregnant woman, without flu syndromes, continues the routine of consultations and tests. However, the exams and doctor consults should be restricted to the essential. The importance of avoiding agglomerations is emphasized, making it necessary to space schedules, and to reinforce guidelines for hygiene and social distance ${ }^{(8)}$. In this context, many women have attended consultations unaccompanied, or still haven't had the opportunity to share that moment with their partner, who, at times, may be instructed not to enter the office.

For women with flu-like symptoms, elective procedures (consultations and routine exams) should be extended by 14 days and, if necessary, be seen in isolation from other patients ${ }^{\left({ }^{8}\right)}$. In addition, pregnant women with a positive diagnosis for Covid-19 are apprehensive about the uncertainties surrounding the vertical transmission of the virus to newborns, making this moment even more delicate. A more recent study pointed to the possibility of vertical transmission of the virus in a severe case of Covid-19 infection, and SARS-CoV-2 may even be identified in samples of placental and fetal membranes ${ }^{(9-10)}$. 


\section{Loneliness in childbirth}

If pregnancy is understood as a crisis, childbirth is considered by Maldonado as a critical, unpredictable and unknown moment, over which we have no control. The author uses the term "leap of faith" to better demonstrate the perspective regarding the woman's experience at that moment, which is sharpened in situations in which there are crises in other spheres ${ }^{(3)}$, such as in the current context of a SARS-CoV-2 pandemic.

Thus, in addition to trailing a lonely path during pregnancy, the moment of delivery is also followed by the insecurity of not being able to count on the companion of your choice. This is because, with the pandemic scenario, the MS recommends restrictions on the number of people present at the time of birth. This guidance has been followed in most Brazilian maternity hospitals and may interfere in the planning of those who thought their births with more than one companion, such as a doula, partner or other family and friends.

There is also the impossibility of relaying companions in the prepartum and childbirth period, who should be screened before entering the maternity ward, since people with flu-like symptoms, comorbidities and/or belonging to risk groups are not allowed. At this point, women have struggled to find a person available to be with them throughout the parturition process and often need to change the chosen person, if that person does not meet the established criteria. In view of the need for the companion to be absent, being the exchange impossible, the possibility of overloading the nursing team in the process of monitoring the parturient, puerperal woman and the basic care of the newborn is pointed out. However, the presence of a companion must be ensured by the institution, as provided by law ${ }^{(11)}$.

It is also noteworthy, as an example, that paternity leave ensures that the parent is released from work activities for five days from birth, without taking into account the period of labor, which can extend for days. This restriction makes it impossible for many men to monitor the birth of their child, distancing them from the family unit and jeopardizing the paternity process, which contributes to an even more lonely motherhood, especially in this initial period.

Another change in the context of birth is that, regardless of the parturient's infection status, professionals, such as obstetric nurses, who provide direct assistance to women have been instructed to adopt precautionary measures, thus avoiding physical contact. In this sense, major implications are experienced in childbirth care, since the absence of direct contact with the pregnant woman makes it difficult to use non-pharmacological methods for pain relief, such as massage, support for squatting, among others. In addition, the woman sometimes lacks support to deal with the feelings that arose at the time of delivery, demanding greater proximity to the professionals. This type of support is offered through hugs, handshakes and words of encouragement spoken close to the ear ${ }^{(12)}$. The absence of this support can have repercussions on the professional-parturient connection, which is crucial for a satisfactory experience in this phase.

Furthermore, the use of personal protective equipment (PPE) distances the relationship between those who assist and those who experience childbirth. The use of this equipment, which is essential to ensure the protection of both women and professionals, cause strangeness, as it requires the use of a cap, goggles, mask, gloves, among others. The use of a mask by the parturient is also recommended, which can cause discomfort during the process. In addition, such devices make it difficult to look into the eyes, the perception of the smile, as well as other manifestations that reassure women at the time of delivery, promoting a split in the process of creating an intimate connection for this care.

In situations where women are suspected or tested positive for Covid-19, the contact restrictions are even greater, as it requires isolation of women in private rooms throughout the hospital stay. In addition, the team's attire is added with aprons and face shields, with a reduction in the number of professionals who came into contact with the woman. This scenario of detachment accentuates the feeling of loneliness. It should be noted that in the occurrence of a confirmed infection by SARS-CoV-2, there is no indication for cesarean section or anticipated delivery, unless there is actual clinical motivation ${ }^{(8)}$.

\section{The exacerbation of puerperal loneliness}

Maldonado says that situating pregnancy as a crisis period does not mean that the critical period ends after delivery. On the contrary, most changes occur precisely with the arrival of the child, this period being understood as "continuity of the crisis" ${ }^{\prime \prime(3)}$.

In a usual way, the puerperium is a solitary moment, in which there is greater instability and emotional vulnerability, due to the drastic changes and new adaptations that take place in the family and psychological sphere ${ }^{(13)}$. It is a period in which it is possible to feel, in addition to physical pain (childbirth, breastfeeding and tiredness), strong emotional pain. This is undoubtedly, the moment in the entire maternal cycle when the woman most needs support from her 
social group. With the advent of the pandemic, loneliness becomes even more real, without the presence of the faceto-face support network, abruptly changing the arrival and reception of the newborn and the "new mother".

Thus, the puerperal women are experiencing the exacerbation of this loneliness from the moment that follows childbirth, until the return to their homes. According to the MS Recommendations Manual, there is an impossibility of visits by family members, friends, or anyone else at the institution where the birth took place, even though the stay of the woman and/or newborn in the unit is prolonged ${ }^{(8)}$.

Bearing in mind that the parturient now has the possibility of a single companion, without relay, we can exemplify the following: in a scenario in which the mother of the parturient is the choice for accompanying the childbirth, her/his partner will only be able to meet their child at home. Although it is a highly recommended measure, it takes away the meaning that surrounds that immediate moment, when the woman, overflowing oxytocin, wishes to show the world her child. As a result, it is important to keep a sharp eye on the professionals in this puerperal beginning, to identify the predisposition to postpartum depression.

The Manual of Recommendations for Assistance to Pregnant Women and Woman in Postpartum in the face of the Covid-19 Pandemic, also provides recommendations on puerperal care, safe discharge and contraception during the Covid-19 pandemic. In short, early hospital discharge should be indicated when the general well-being of women and newborns is verified, regardless of the infection status. When, in the case of puerperal women at higher risk for complications, whether due to the presence of comorbidities during pregnancy/delivery and/or when conditions of social vulnerability are identified, hospital discharge should only be carried out when the condition has stabilized and/or the referral is made to the Family Health Team (ESF), which monitor the situation systemically ${ }^{(8)}$.

These guidelines are based on an Iranian research that showed a rapid deterioration in the clinical condition of pregnant women and puerperal women infected with SARSCoV-2, which points to the need for systematic monitoring. Therefore, under no circumstances should women be abandoned after hospital discharge, and it is necessary for the family to be informed and attentive to the appearance of risk symptoms that require quick referral to health services, such as difficulty in breathing, flapping of the nasal wings, intercostal retraction, cyanosis, lethargy, temperature changes ${ }^{(8)}$.

In the home environment, puerperal women, regardless of their health condition, should avoid the presence of anyone who does not live in their homes, remembering that most of those infected with the new coronavirus can be asymptomatic. Women with suspected or confirmed symptoms of COVID-19-19 should be isolated with the newborn in a private room in the house, maintaining a distance of at least one meter between the bed and the crib. In addition, they should follow the recommendations of the World Health Organization regarding frequent and correct hand washing, especially after touching the nose/mouth and immediately before picking up the baby ${ }^{(8)}$.

Although these conducts are indispensable, it is understood that this is/will be a difficult journey, given that it is a moment of transformation, reframing and recognition for women. Many of them have, for example, difficulties in managing lactation in the early days, and may reverberate in the need to access a milk bank and/or a health unit together with the newborn, which involves risks and sometimes causes discouragement. In addition, one must bear in mind the fear that these women may have in transmitting the disease to their newborns. In any case, there is a greater risk for weaning.

Maldonado corroborates the importance of breastfeeding, when saying that this is more than just a physiological process. It is a channel for psychosocial communication between mother and baby, and the moment of the baby's return to the mother's body, where the newborn can gradually re-elaborate the separation that occurred during childbirth $^{(3)}$. In the meantime, Primary Health Care professionals, especially nurses, must be prepared to, with the caution entailed and use of PPE, perform at least one puerperal visit between seven to ten days postpartum, in order to supply, among others, existing demands, especially those that affect problems with breastfeeding.

In this context, professionals can use technologies to strengthen ties and provide support where possible, including using messaging and video applications to observe and demonstrate some practices. An experience report of lactation nurse consultants, from Fortaleza, Ceará, Brazil, demonstrated the use of these technologies successfully, where in a period of one month there were 37 consultations, 27 of which were held exclusively through digital media. Through video consults, it was possible to assess the entire dynamics of breastfeeding, correct non-conformities and provide guidance on important issues ${ }^{(14)}$. Thus, assistance to women in the pregnancy-puerperal cycle can continue to be carried out, without major losses, with the use of these technologies.

\section{FINAL CONSIDERATIONS}

The pregnancy-puerperal cycle causes great physical, hormonal, psychological and social changes for the woman 
who experiences it, being loneliness a very frequent feeling. In times of the pandemic caused by the SARS-CoV-2 virus, there is a tendency for this solitary experience to exacerbate, as distance or social isolation is essential and care changes are recommended in order to ensure the protection of all actors involved.

It is considered that this reflection can guide health professionals, especially the work of nurses in the scope of obstetrics, so that during the assistance to women in the pregnancy-puerperal cycle, they pay attention to the subtleties of feelings of loneliness that can interfere with the maternal-fetal well-being. Based on this knowledge, it is possible for nurses to create strategies to overcome the difficulties imposed by the pandemic, better preparing women for pregnancy, childbirth and the puerperium, including through digital technologies for individual consultations and the establishment of support networks in a group of pregnant women/puerperal women.

\section{REFERENCES}

1. Ramalho C. COVID-19 na gravidez, o que sabemos? [editorial]. Acta Obstet Ginecol Port. 2020 [cited 2020 May 05];14(1):6-7. Available from: http://www. scielo.mec.pt/pdf/aogp/v14n1/v14n1a01.pdf

2. Silva J, Melo MFAQ. Um espelho de duas faces: ser ou não ser mãe? Rev Polis Psique. 2020;10(1):85-106. doi: https://doi.org/10.22456/2238-152X.89721

3. Maldonado MTP. Psicologia da gravidez: parto e puerpério. 4. ed. Petropolis: Vozes; 1980.

4. Hiremath P. Need for psychological assessment during pregnancy: a nursing perspective. Glob J Nurs Forensic Stud. 2016 [cited 2020 May 05];1(3):10710. Available from: https://www.omicsonline.org/open-access/need-forpsychological-assessment-during-pregnancy-a-nursing-perspective-pdf

5. Santos CF, Vivian AG. Apego materno-fetal no contexto da gestação de alto risco: contribuições de um grupo interdisciplinar. Diaphora. 2019 [cited 2020 Apr 30];18(2):9-18. Available from: http://www.sprgs.org.br/diaphora/ojs/ index.php/diaphora/article/view/159
6. Wu Y, Zhang C, Liu H, Duan C, Li C, Fan J, et al. Perinatal depressive and anxiety symptoms of pregnant women along with COVID-19 outbreak in China. Am J Obstet Gynecol. 2020;223(2):240.e1-240.e9. doi: https://doi.org/10.1016/j. ajog.2020.05.009

7. Amorim MMR, Takemoto MLS, Fonseca EB. Maternal deaths with COVID-19: a different outcome from mid to low resource countries? [letter] Am J Obstet Gynecol. 2020;223(2):298-9. doi: https://doi.org/10.1016/j.ajog.2020.04.023

8. Ministério da Saúde (BR), Secretaria de Atenção Primária à Saúde. Departamento de Ações Programáticas Estratégicas. Manual de Recomendações para a Assistência à Gestante e Puérpera Frente à Pandemia de COVID-19. Brasilia (DF): Ministério da Saúde; 2020 [cited 2020 Apr 30]. [Nota Informativa no 13/2020 SE/GAB/SE/MS]. Available from: http://189.28.128.100/dab/docs/portaldab/ documentos/corona/manual_recomendacoes_gestantes_covid19.pdf

9. Penfield CA, Brubaker SG, Limaye MA, Lighter J, Ratner AJ, Thomas KM, et al. Detection of severe acute respiratory syndrome coronavirus 2 in placental and fetal membrane samples. Am J Obstet Gynecol MFM. 2020;2(3):100133. doi: https://doi.org/10.1016/j.ajogmf.2020.100133

10. Zhao X, Jiang Y,Zhao Y,XXH, LiuC, QuF,etal. Analysis ofthe susceptibility to COVID-19 in pregnancy and recommendations on potential drug screening. Eur J Clin Microbiol Infect Dis. 2020;23:1-12. doi: https://doi.org/10.1007/s10096-020-03897-6

11. Presidência da República (BR). Lei № 11.108, de 7 de abril de 2005. Altera a Lei no 8.080, de 19 de setembro de 1990, para garantir às parturientes 0 direito à presença de acompanhante durante 0 trabalho de parto, parto e pós-parto imediato, no âmbito do Sistema Único de Saúde - SUS. Diário Oficial da União. 2005 abr 08 [cited 2020 Apr 10];142(67 Seção 1):1. Available from: https://pesquisa.in.gov.br/imprensa/spp/visualiza/index. jsp?data $=08 / 04 / 2005 \& j$ ornal $=1 \&$ pagina $=1 \&$ tota|Arquivos= 176

12. Oliveira OS, Couto TM, Gomes NP, Campos LM, Lima KTRS, Barral FE. Bestpractices in the delivery process: conceptions from nurse midwives. Rev Bras Enferm. 2019;72(2):455-62. doi: https://doi.org/10.1590/0034-7167-2018-0477

13. Frota CA, Batista CA, Pereira RIN, Carvalho APC, Cavalcante GLF, Lima SVA, et al. A transição emocional materna no período puerperal associada aos transtornos psicológicos como a depressão pós-parto. Rev Eletrôn Acervo Saúde. 2020;48 Supl:e3237. doi: https://doi.org/10.25248/reas.e3237.2020

14. Lima ACMACC, Chaves AFL, Oliveira MG D, Lima SAFCC, Machado MMT, Oriá MOB. Breastfeeding consultancy during the COVID-19 pandemic: experience report. Esc Anna Nery. 2020;24(spe):e20200350. doi: https://doi. org/10.1590/2177-9465-ean-2020-0350 


\section{- Authorship contribution:}

Conceptualization: Gilvânia Patrícia do Nascimento Paixão, Luana Moura Campos, Jordana Brock Carneiro. Data curation: Gilvânia Patrícia do Nascimento Paixão, Luana Moura Campos, Jordana Brock Carneiro.

Formal analysis: Gilvânia Patrícia do Nascimento Paixão, Luana Moura Campos, Chalana Duarte de Sena Fraga. Methodology: Gilvânia Patrícia do Nascimento Paixão, Luana Moura Campos, Jordana Brock Carneiro. Validation: Gilvânia Patrícia do Nascimento Paixão, Chalana Duarte de Sena Fraga.

Writing - original draft: Gilvânia Patrícia do Nascimento Paixão, Luana Moura Campos, Jordana Brock Carneiro,

Chalana Duarte de Sena Fraga.

Writing - review and editing: Gilvânia Patrícia do Nascimento Paixão, Luana Moura Campos, Jordana Brock Carneiro, Chalana Duarte de Sena Fraga.

The authors declare that there is no conflict of interest.

\section{- Corresponding author:}

Gilvânia Patrícia do Nascimento Paixão

Email: gilvania.paixao@gmail.com

\section{Associate editor:}

Dagmar Elaine Kaiser 